\title{
ESTIMATION OF COMBINING ABILITY AND HETEROSIS FOR SOME MAIZE INBRED LINES AND ITS SINGLE CROSSES \\ Attia, A.N. ${ }^{\star}$; M.S. Sultan ${ }^{*}$ M.A. Badawi ${ }^{\star}$; M.A. Abdel-Moneam ${ }^{*}$ and A.R.M. Al-Rawi \\ Agronomy Department, Faculty of Agriculture, Mansoura University, Egypt.
}

\section{ABSTRACT}

Two field experiments were conducted out during 2012 and 2013 seasons to estimate combining ability, heterosis for six inbred lines (Three American inbreds: P97, B73and Oh.43 and three Egyptian inbred lines: R39, Inb.1021 and Inb.1004) and its $F_{1}$ crosses. The most important results obtained from this investigation can be summarized as follows:

- The differences among means of parental inbreds and also among means of crosses were significant or highly significant for all studied traits.

- Mean squares of crosses were highly significant for all studied traits, indicating wide range of genetic variability among the studied crosses and this is primary requirement for further computation.

- Both general and specific combining abilities mean squares were found to be highly significant for all studied traits.

- GCA/SCA variances ratios were found to be lower than unity for six traits i.e. time to tassel emergency, time to silk emergency, number of rows/ear, number of kernels/row, grain yield/plant and shelling percentage and higher than unity for plant height and 100-Kernel weigh.

- Significant positive general combining ability (GCA) effects were found for most studied traits. The best combiners were P2 (P79) and P4 (Inb.1021) for earliness traits; P5 (Inb.1004) and P6 (Oh.43) for plant height; P5 (Inb.1004) for number of rows/ear; P1 (R39) for number of grains/row; P2 (P97), P3 (B73) and P4 (Inb.1021) for 100-grain weight; P1 (R39) for grain yield/plant; P1 (R39) and P2 (P97) for shelling percentage.

- Significant positive specific combining ability (SCA) effects were found for most studied traits. The best cross combinations $\mathrm{P} 3 \times \mathrm{P} 4$ for number of rows/ear; P1 $\mathrm{PP} 5$ for number of grains/row; $\mathrm{P} 1 \times \mathrm{P} 3, \mathrm{P} 1 \times \mathrm{P} 6, \mathrm{P} 2 \times \mathrm{P} 3, \mathrm{P} 2 \times \mathrm{P} 5, \mathrm{P} 3 \times \mathrm{P} 5$ and $\mathrm{P} 4 \times \mathrm{P} 6$ for

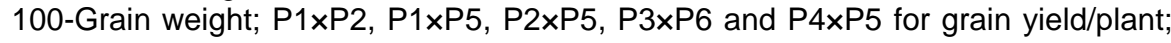
$\mathrm{P} 1 \times \mathrm{P} 5, \mathrm{P} 3 \times \mathrm{P} 6$ and $\mathrm{P} 4 \times \mathrm{P} 5$ for shelling percentage.

- Results showed significant or highly significant heterosis over mid-parents and better parents for all studied traits. The best crosses over mid and better parents were $(\mathrm{P} 1 \times \mathrm{P} 5)$ for number of rows/ear; $(\mathrm{P} 1 \times \mathrm{P} 6)$ for number of grains/row; $(\mathrm{P} 2 \times \mathrm{P} 5)$ for100-grain weight; $(\mathrm{P} 1 \times \mathrm{P} 6)$ for grain yield and $(\mathrm{P} 1 \times \mathrm{P} 4)$ for shelling percentage.

- The study recommends using inbred line P3 (B73) and crosses P1×P2, P1×P3 and $\mathrm{P} 3 \times \mathrm{P} 6$ in breeding program of maize to improve the yield and its components where they recorded the highest value of the grain yield/plant and gave a better combining ability.

Keywords: Maize, Inbred lines, Crosses, Combining ability, Heterosis.

\section{INTRODUCTION}

In Egypt, maize (Zea mays L.) is considered as one of the main cereal crops, comes the third after wheat and rice. Maize is very essential either for the human food or animal feeding and a common ingredient for 
industrial products. It plays a vital source of daily human food because their flour mixed with wheat flour by $20 \%$ for bread making. Also, maize is used as a feed for livestock whether fresh, silage or grains. The grains also have many industrial uses, including transformation into plastics and fabrics. Thus, there is a critical need to increase the production of maize to face the gab between production and consumption. In this respect, National Maize Research Program, breeders and geneticists who are interested in corn improvement need conclusive information related to the identification of inbred lines, single crosses and three-ways crosses.

Identification of heterosis initially to studies conducted by Darwin (1876) in which he observed that $F_{1}$ maize hybrids were taller than either parents in young and mature stages of growth. With this idea of heterosis or hybrid vigor in mind, plant and animal breeders have capitalized on this occurrence to make genetic improvements. Breeders and geneticists make great efforts to benefit from heterosis Phenomenon. In this respect, Amiruzzaman et al. (2010) reported that heterosis ranged from -17.60 to 9.71 $\% ;-20.41$ to $8.04 \%$; -13.89 to $7.54 \%$ and -6.17 to $14.48 \%$ for yield/plant, number of kernels/ear, length of ear and 1000-kernel weight, respectively. Kernel weight showed maximum heterotic contribution to high yield. ElGhonemy and Ibrahim (2010) found that four crosses i.e. Gm.220 x Gm.205 (33.91), Gm.206 x Gm.203 (33.51), Gm.220 x Gm.203 (33.37) and Gm.206 x Gm.220 (33.31) ardab/fed show significant positive heterotic effects relative to commercial hybrid SC 162 (30.26) ardab/fed. Muhammad et al. (2010) showed that inbred lines significantly differed among each other for all traits. The estimates of components of genetic variation revealed that non-additive genetic effects were more pronounced in the inheritance of plant height, days to $50 \%$ tasseling, days to $50 \%$ silking, ear height and grain yield/plant. Guznay and Sadalla (2011) evaluated performance of genotypes, estimation of genetic parameters (phenotypic and genotypic variance, heritability and expected genetic advance) as well as the estimation of stability and genetic resultant. They reported that highly significant differences were found between genotypes for all characters. Heritability in broad sense was high for $50 \%$ silking and tasseling, plant and ear heights and number of rows/ear. Sultan et al. (2011) stated that mean squares due to general and specific combining ability were highly significant for all studied traits. Haddadi et al. (2012) reported that combined analysis of variance showed significant mean squares of general combining ability (GCA) and specific combing ability (SCA) indicating the importance of both additive and non-additive genetic effects for these traits. Solomon et al. (2012) found that heterosis was more important for yield-related traits than it was for ear aspects. Heterosis for most traits was mostly dependent on dominance genetic effects of parental lines. Parents and $F_{1}$ performance were highly correlated with general combining ability effects and mid-parent values, respectively, for most traits. Attia et al. (2013) revealed that significant or highly significant heterosis for all studied traits. Cross P $3 \times \mathrm{P} 6$ was the best, with highly significant negative heterosis over mid and better parents for number of days to $50 \%$ tasseling. Cross P2×P3 recorded the highest negative heterosis over mid and better parents for number of days to $50 \%$ silking. El-Diasty (2013) cleared that 
parent No. $3(103.7 \mathrm{~g})$ and No. $5(102.35 \mathrm{~g})$ yielded the highest $F_{1}$ hybrid $3 \times 5$ $(273 \mathrm{~g})$. The results also showed that all $F_{1}$ hybrids exceeded their parents and all other parents in number of rows/ear. Sultan et al. (2013) showed that GCA and SCA mean squares were significant for all studied traits except, stem diameter under normal nitrogen level for GCA and ear leaf area under normal nitrogen level for GCA and SCA. Abdel-Moneam et al. (2014) revealed that general and specific combining ability (GCA and SCA) mean squares were significant or highly significant for all studied traits, except shelling percentage under normal nitrogen level at GCA and SCA. They added that significant or highly significant heterosis over mid or better parents for all studied traits Aminu et al. (2014) showed that there were high and significant level of genetic variability among the parental lines used and their hybrids for almost all the traits study, thus suggesting the possibility for genetic improvement. Guerrero et al. (2014) reported that the greatest effects of SCA for (FY) were cross AN- 447XCML-264 (17.56 tha-1) and AN388RXCML-319 (16.54 t.ha-1), in (GY) were cross AN- 447XCML-315 (1.94 t.ha-1) and B-40XCML-319 (1.78 tha-1). Hemalatha et al. (2014) decided that combining ability analysis was done using $45 \mathrm{~F} 1$ hybrids and their parents obtained from a diallel mating design for six morphological parameters. Both general and specific combining ability variances were highly significant for almost all the characters, except anthesis-silking interval. Wattoo et al. (2014) reported that highly significant mean squares due to general combining ability, specific combining ability and reciprocal effects were observed for all traits under both water regimes. Components of variation exhibited greater estimates for GCA variance $\left(\sigma^{2} g\right)$ than SCA variance $\left(\sigma^{2} s\right)$ for majority of the traits under both normal and stress conditions depicting the predominant role of additive genetic component.

Therefore, this investigation was established to estimate general, specific combining abilities and heterosis among some maize inbred lines and their $F_{1}$ single crosses under the environmental conditions of Dakahlia district, Egypt.

\section{MATERIALS AND METHODS}

Two field experiments were conducted out during 2012 and 2013 seasons to estimate combining ability and hybrid vigor of some maize lines and its single crosses. Six lines were: 3 American inbreds (P 97, B 73 and Oh. 43) and 3 Egyptian inbreds (R 39, Inb. 1021 and Inb. 1004). The seeds of American inbred lines were obtained from Dr.Stephen Moose at the University of Illinois, USA.While the seeds of local inbred lines were obtained from Maize Research Department, Field Crop Research Institute, Agriculture Research Center (ARC), Ministry of Agriculture and Land Reclamation, Egypt.

In $20^{\text {th }}$ June 2012 growing season, the seeds of all parental inbred lines were planted in the Farm of the Agronomy Department, Faculty of Agriculture, Mansoura University. All parental inbred lines were crossed according to a half diallel crosses mating design to obtain 15 single crosses. In $10^{\text {th }}$ June 2013 growing season, all 21 genotypes, which included 6 
parental inbred lines and $15 F_{1}$ single crosses were cultivated using the dry method (Afir).

The experimental design was randomized complete block design with four replicates. Each experimental unit consist of 4 ridges .One ridge is a repeater along the 3-meter contains 12 plants, the distance between the plant and other $25 \mathrm{~cm}$ and between the ridges and other $70 \mathrm{~cm}$. Soil type is clayey texture with organic matter percentage of $1.7 \%, \mathrm{pH} 7.6$ and EC $1.8(\mathrm{ds} / \mathrm{m})$ at $25^{\circ} \mathrm{C}$.

The preceding winter crop was Egyptian clover (Trifolium alexandrinum L.). The soil was ploughed two times then ridged. Calcium super phosphate $\left(15.5 \% \mathrm{P}_{2} \mathrm{O}_{5}\right)$ was incorporated in the soil during tillage operation at a rate of $150 \mathrm{~kg} / \mathrm{fed}$. Maize seeds were sown at $25 \mathrm{~cm}$ between hills at the rate of 2-3 grains/hill on one side of the ridge using the dry methods (Afir). Plants were thinned later to one plant per hill before the first irrigation, providing a population density of about 24000 plants/fed. The first irrigation was applied after 21 days from planting and then at 15 days intervals during the growing seasons. Nitrogen fertilizer in the form of Urea $(46 \% \mathrm{~N})$ was added at the rate of $120 \mathrm{~kg} \mathrm{~N} / \mathrm{fed}$ in two equal doses, the first dose was after thinning and before the first irrigation, and the second dose before the second irrigation. Weeds were controlled by using manual method before irrigation. Other agricultural practices were carried as recommended from Ministry of Agriculture and Land Reclamation.

\section{Studied Characters:}

\section{Studied characters were:}

1 -Time to $50 \%$ tassel emergence (days)

2-Time to $50 \%$ silk emergence (days)

5- Number of kernels/row

3-Plant height $(\mathrm{cm})$

6-100- Kernels weight $(\mathrm{g})$

4-Number of rows/ear

7- Grain yield/plant (g)

8- Shelling percentage

A- Diallel analysis for general (GCA) and specific (SCA) combining ability.

Fifteen single crosses comprise a half diallel among six inbred parents. Data of parents and crosses were analyzed as randomized complete block design separately. The sum of squares of crosses was partitioned to general and specific combining ability following method 4 model 1 (fixed effects) of (Griffing, 1956) as shown in Table 1.

Table 1: Analysis of variance and expected mean squares for combining ability analysis.

\begin{tabular}{|l|c|c|c|}
\hline \multicolumn{1}{|c|}{ S.V } & D.f & M.S & E.M.S \\
\hline GCA & $\mathrm{P}-1$ & $\mathrm{Mg}$ & $\sigma^{2} e^{2}+(p+2)(1 / p-1) \sum g^{2} i$ \\
\hline SCA & $\mathrm{P}(\mathrm{p}-1) / 2$ & $\mathrm{Ms}$ & $\sigma^{2}{ }^{2}+2 / p(p-1) \sum i \sum j s^{2} i j$ \\
\hline Error & $(\mathrm{r}-1)(\mathrm{c}-1)$ & $\mathrm{Me}$ & $\sigma_{e}^{2}$ \\
\hline
\end{tabular}

$M e=$ The error mean squares of the main randomized complete block design divided by number of replications.

$P=$ Number of parents. 
The relative importance of GCA to SCA was expressed as follows:

Ms $=$ Means of squares.

$$
\frac{K^{2} G C A}{K^{2} S C A}=\frac{\left[\left(M S_{G C A}-M s_{e}\right) /(P+2)\right]}{\left[M S_{S C A}-M s_{e}\right]}
$$

$P=$ Number of parents.

$\mathrm{K}^{2}=$ average squares of effects.

General combining ability (GCA) effects for the inbred parents, specific combining ability (SCA) effects for cross combinations and their respective standard errors were computed using formula given in Griffing (1956).

\section{B- Estimates of heterosis.}

Heterosis as proposed by Mather and Jinks (1982) was determined for individual cross as the percentage deviation of $F_{1}$ means from midparents means (MP) and better parent (BP) and expressed as percentages as follows:

$$
\text { 1- Heterosis over the mid-parents } \%=\frac{\left(\overline{F_{1}}-\overline{M P}\right)}{\overline{M P}} \times 100
$$

The significance of heterosis effect for $F_{1}$ values from the mid-parents and better parent were tested according to the following formula:

1- LSD for mid-patent heterosis $=$ t 0.05 or $0.01 \times \sqrt{(3 M S e / 2 r)}$

2- LSD for better-patent heterosis = 0.05 or $0.01 \times \sqrt{(2 M S e / r)}$

$t=$ Tabulated " $\mathrm{t}$ " value at a stated level of probability for the experimental error degree of freedom.

$M s e=$ Mean squares of the experimental error from the analysis of variance. $r=$ Number of replicates.

Samples of ten guarded plants were taken at random from middle two ridges of each plot to determine the quantitative and qualitative characters.

Statistical Analysis:

All obtained data were statistically analyzed according to the technique of analysis of variance (ANOVA) for the randomized complete block design with three replicates as published by Gomez and Gomez (1984) by using "MSTAT-C " computer software package. New Least Significant of Difference (NLSD) method was used to test the differences between treatment means at $5 \%$ level of probability as described by Waller and Duncan (1969). 


\section{RESULTS AND DISCUSSION}

- Mean performance of maize inbred lines and their $F_{1}$ single crosses.

Data listed in Table 2 revealed that significant or highly significant differences were detected due to the effect of maize inbred lines and their $F_{1}$ single crosses on time to $50 \%$ tassel emergence (days). Planting inbred line Inb.1021 (56.66 days) and single cross R39×Oh.43 (55.66 days) give the highest number of days to $50 \%$ tassel emergence (latest genotypes). While, the lowest number (46.66 and 43.33 days) was produced from sowing inbred line B73 and single cross Inb. $1021 \times$ Oh.43 (earliest genotypes), respectively. Concerning time to $50 \%$ silk emergence (days), it is clearly showed that significant or highly significant differences among the studied inbred lines and their $F_{1}$ single crosses. It could be concluded that, Planting inbred line R39 and Oh.43 (61.33 days) and single cross R39×Oh.43 (60 days) recorded the highest number of days to $50 \%$ silk emergence (latest genotypes). Meanwhile, the lowest number of days was produced from sowing inbred line B73(53.33 days) and single crosses i.e. Inb.1021×Oh.43(48.66 days) (earliest genotypes).

Data listed in Table 2 revealed that highly significant differences were detected on average of plant height $(\mathrm{cm})$ among the studied inbred lines and their $F_{1}$ single crosses. The results indicated that the tallest plant was produced from planting inbred line Inb.1021 and single cross R39×B73. The corresponding data were $190.66 \mathrm{~cm}$ and $270.50 \mathrm{~cm}$, respectively. On the other hand, the shortest plant was produced from planting inbred line Oh.43 $(123.16 \mathrm{~cm})$ and single cross Inb.1004×Oh.43 $(183.33 \mathrm{~cm})$.

Regarding to number of rows/ear, significant differences were detected among the studied inbred lines and highly significant differences were observed among $F_{1}$ single crosses. The inbred line B73 and single cross R39 Inb.1004 gave the highest number of rows/ear. The corresponding data were 16.00 and 20.00 , respectively. On the other hand, planting inbred lines R39, Inb.1021, Oh.43 and single cross P97×Inb.1021 (12.00) gave the lowest number of rows/ear, as shown in Table 2.

Number of kernels/row significantly affected by studied inbred lines and their $F_{1}$ single crosses (Table 2). Planting inbred line Inb.1004 and single cross R39xInb.1004 gave the highest number of kernels/row. The corresponding data were 30.00 and 41.00 , respectively. On the other hand, planting inbred line Oh.43 (14.00) and single cross Inb.1004×Oh.43 (32.33) gave the lowest number of kernels/row, as shown in Table 2.

With respect to 100 - Kernel weight $(\mathrm{g})$, data presented in Table 2 showed that highly significant differences were detected on 100- Kernel weight among the studied inbred lines and their $F_{1}$ single crosses. The results indicated that inbred line B73 $(18.10 \mathrm{~g})$ and single cross P97×B73 $(30.93 \mathrm{~g})$ had maximum values of $100-$ Kernel weight. While, the lowest values of $100-$ Kernel weight were obtained from planting inbred line P97 (12.52 g) and single cross R39×Inb.1004(19.84 g).

Regarding to grain yield/plant (g), data presented in Table 2 showed that highly significant differences were detected on grain yield/plant among the studied inbred lines and their $F_{1}$ single crosses. The highest values of 
grain yield/plant were shown by inbred line B73 (121.72 g) and single cross R39×P97 (287.11 g). While, the lowest values of grain yield/plant were obtained from planting inbred line Oh.43 (27.75 g) and single cross P97×Inb.1021 (130.31 g).

Shelling percentage significantly affected by studied inbred lines and their $F_{1}$ single crosses. Planting inbred line P97 and single cross R39×P97 gave the highest shelling percentage. The corresponding data were $84.07 \%$ and $90.70 \%$, respectively. On the other hand, planting inbred line Inb.1021 $(67.11 \%)$ and single cross Inb. $1004 \times$ Oh.43 $(75.43 \%)$ gave the lowest shelling percentage.

It could be stated that the variation among maize inbred lines and their $F_{1}$ single crosses in these traits may be due to the amount of diversity among the tested genotypes which could be manipulated for further improvement in maize breeding. Similar results were reported by Amanullah et al. (2011), Sultan et al. (2011) , Attia et al. (2013), El-Diasty (2013), AbdelMoneam et al. (2014) and Guerrero et al. (2014).

Table 2: Mean performance of maize inbred lines and their $F_{1}$ single crosses for all studied traits during 2013 summer season.

\begin{tabular}{|c|c|c|c|c|}
\hline Genotypes & $\begin{array}{l}\text { Time to } \\
\text { tassel } \\
\text { emerge. } \\
\text { (day) }\end{array}$ & $\begin{array}{l}\text { Time to silk } \\
\text { emerge. } \\
\text { (day) }\end{array}$ & $\begin{array}{c}\text { Plant } \\
\text { height }(\mathrm{cm})\end{array}$ & $\begin{array}{l}\text { Number of } \\
\text { rows/ear }\end{array}$ \\
\hline P1 (R39) & 54.66 & 61.33 & 155.66 & 12.00 \\
\hline P2 (P97) & 50.33 & 56.66 & 149.66 & 14.00 \\
\hline P3 (B73) & 46.66 & 53.33 & 177.66 & 16.00 \\
\hline P4 (Inb.1021) & 56.66 & 61.00 & 190.66 & 12.00 \\
\hline P5 (Inb.1004) & 49.66 & 57.00 & 147.00 & 14.00 \\
\hline P6 (Oh.43) & 55.66 & 61.33 & 123.16 & 12.00 \\
\hline Mean parents & 51.52 & 57.23 & 171.71 & 14.00 \\
\hline NLSD at $5 \%$ & 3.71 & 4.32 & 8.10 & 3.56 \\
\hline P1×P2 (R39×P97) & 47.00 & 50.00 & 258.16 & 18.00 \\
\hline P1×P3 (R39×B73) & 47.33 & 53.33 & 270.50 & 16.00 \\
\hline $\mathrm{P} 1 \times \mathrm{P} 4(\mathrm{R} 39 \times \ln 6.1021)$ & 48.33 & 53.66 & 269.16 & 16.00 \\
\hline P1×P5 (R39×Inb.1004) & 51.33 & 59.00 & 251.33 & 20.00 \\
\hline P1×P6 (R39×Oh.43) & 55.66 & 60.00 & 231.33 & 16.00 \\
\hline P2×P3 (P97×B73) & 46.00 & 51.00 & 244.00 & 16.00 \\
\hline P2×P4 (P97×Inb.1021) & 44.33 & 50.00 & 240.66 & 12.00 \\
\hline P2×P5 (P97×Inb.1004) & 47.00 & 52.00 & 225.00 & 18.66 \\
\hline P2×P6 (P97×Oh.43) & 46.33 & 52.33 & 234.00 & 18.00 \\
\hline P3×P4 (B73×Inb.1021) & 47.33 & 49.33 & 249.50 & 16.66 \\
\hline P3×P5 (B73×Inb.1004) & 53.00 & 54.66 & 250.33 & 14.00 \\
\hline P3×P6 (B73×Oh.43) & 49.33 & 53.33 & 263.00 & 16.00 \\
\hline P4×P5 (Inb.1021×Inb.1004) & 52.00 & 56.66 & 218.33 & 18.66 \\
\hline P4×P6 (Inb.1021×Oh.43) & 43.33 & 48.66 & 205.00 & 16.00 \\
\hline P5×P6 (Inb.1004×Oh.43) & 47.00 & 51.00 & 183.33 & 18.00 \\
\hline Mean crosses & 48.35 & 53.00 & 239.57 & 16.66 \\
\hline NLSD at $5 \%$ & 4.48 & 4.16 & 15.54 & 3.31 \\
\hline
\end{tabular}


Table 2: Continue ......

\begin{tabular}{|c|c|c|c|c|}
\hline \begin{tabular}{|ll} 
Genotypes & Characters \\
\end{tabular} & $\begin{array}{l}\text { Number of } \\
\text { kernels/row }\end{array}$ & $\begin{array}{l}\text { 100-Kernel } \\
\text { weight }(\mathrm{g})\end{array}$ & $\begin{array}{l}\text { Grain yield/ } \\
\text { plant }(\mathrm{g})\end{array}$ & $\begin{array}{c}\text { Shelling } \\
\text { percentage }\end{array}$ \\
\hline P1 (R39) & 16.66 & 14.49 & 39.75 & 80.34 \\
\hline P2 (P97) & 24.00 & 12.52 & 59.34 & 84.07 \\
\hline P3 (B73) & 24.66 & 18.10 & 121.72 & 82.27 \\
\hline P4 (Inb.1021) & 18.00 & 17.60 & 55.91 & 67.11 \\
\hline P5 (Inb.1004) & 30.00 & 13.90 & 101.97 & 83.14 \\
\hline P6 (Oh.43) & 14.00 & 16.38 & 27.75 & 77.01 \\
\hline Mean parents & 23.57 & 16.64 & 99.08 & 80.66 \\
\hline NLSD at $5 \%$ & 3.31 & 1.62 & 25.91 & 2.45 \\
\hline $\mathrm{P} 1 \times \mathrm{P} 2(\mathrm{R} 39 \times \mathrm{P} 97)$ & 37.66 & 23.52 & 287.11 & 90.70 \\
\hline $\mathrm{P} 1 \times \mathrm{P} 3(\mathrm{R} 39 \times \mathrm{B} 73)$ & 33.00 & 25.30 & 234.74 & 84.12 \\
\hline $\mathrm{P} 1 \times \mathrm{P} 4(\mathrm{R} 39 \times \ln b .1021)$ & 39.00 & 21.67 & 201.79 & 86.42 \\
\hline P1×P5 (R39×Inb.1004) & 41.00 & 19.84 & 261.88 & 88.47 \\
\hline $\mathrm{P} 1 \times \mathrm{P} 6$ (R39×Oh.43) & 37.33 & 22.54 & 223.48 & 86.55 \\
\hline $\mathrm{P} 2 \times \mathrm{P} 3(\mathrm{P} 97 \times \mathrm{B} 73)$ & 35.33 & 30.93 & 178.39 & 86.40 \\
\hline$\overline{P 2 \times P 4}($ P97× $\operatorname{lnb} .1021)$ & 35.66 & 28.93 & 130.31 & 86.54 \\
\hline P2×P5 (P97×Inb.1004) & 39.33 & 28.53 & 207.23 & 84.16 \\
\hline P2×P6 (P97×Oh.43) & 36.33 & 25.77 & 177.29 & 86.38 \\
\hline $\mathrm{P} 3 \times \mathrm{P} 4(\mathrm{~B} 73 \times \ln b .1021)$ & 37.00 & 26.41 & 160.92 & 79.52 \\
\hline P3×P5 (B73×Inb.1004) & 37.66 & 28.29 & 148.19 & 77.18 \\
\hline P3×P6 (B73×Oh.43) & 34.00 & 25.79 & 256.36 & 88.75 \\
\hline P4×P5 (Inb.1021×Inb.1004) & 35.00 & 26.55 & 175.36 & 81.64 \\
\hline$\overline{\mathrm{P} 4 \times \mathrm{P} 6(\text { (Inb.1021×Oh.43) }}$ & 34.66 & 28.71 & 167.73 & 83.53 \\
\hline P5×P6 (Inb.1004×Oh.43) & 32.33 & 22.47 & 133.74 & 75.43 \\
\hline Mean crosses & 36.35 & 25.68 & 196.30 & 84.38 \\
\hline NLSD at $5 \%$ & 3.83 & 1.51 & 38.59 & 2.08 \\
\hline
\end{tabular}

- General and specific combining abilities.

\section{1- Analysis of variance:}

Mean squares from the analysis of variance for crosses, general combining ability (GCA) and specific combining ability (SCA) for all studied traits are presented in Table 3.

Mean squares of crosses were highly significant for all studied traits, indicating wide range of genetic variability among the studied crosses and this is primary requirement for further computation. These results are in confidence with those of Shalof (2012).

Table 3: Mean squares from the analysis of variance, for general and specific combining ability (GCA \&SCA) for all studied traits.

\begin{tabular}{|c|c|c|c|c|c|}
\hline S.V & D.f & $\begin{array}{l}\text { Time to tassel } \\
\text { emergency }\end{array}$ & $\begin{array}{l}\text { Time to silk } \\
\text { emergency }\end{array}$ & Plant height & $\begin{array}{l}\text { Number of } \\
\text { rows/ear }\end{array}$ \\
\hline Crosses & 14 & 33.59 & 34.62 & 1761.62 & 12.00 \\
\hline GCA & 5 & $15.43^{*}$ & $16.98^{* *}$ & $1240.93^{* *}$ & 4.09 \\
\hline SCA & 9 & 9.20 & 8.52 & 224.04 & 3.95 \\
\hline Error & 28 & 2.39 & 2.07 & 28.80 & 1.31 \\
\hline GCA/SCA & $\ldots$ & 0.48 & 0.58 & 1.55 & 0.26 \\
\hline S.V & D.f & $\begin{array}{l}\text { Number of } \\
\text { kernels/row }\end{array}$ & $\begin{array}{c}\text { 100-Kernel } \\
\text { weight }\end{array}$ & $\begin{array}{l}\text { Grain yield/ } \\
\text { plant }\end{array}$ & $\begin{array}{c}\text { Shelling } \\
\text { percentage }\end{array}$ \\
\hline Crosses & 14 & 17.45 & 29.73 & 6919.61 & 55.98 \\
\hline GCA & 5 & $6.57^{*}$ & $21.43^{* *}$ & $3823.31 *$ & $31.85^{*}$ \\
\hline SCA & 9 & $5.40^{\circ}$ & $3.51^{\circ}$ & 1463.88 & $11.33^{*}$ \\
\hline Error & 28 & 1.75 & 0.27 & 177.55 & 0.52 \\
\hline GCA/SCA & $\ldots$ & 0.33 & 1.63 & 0.71 & 0.72 \\
\hline
\end{tabular}

${ }_{\star}^{\text {and }} \star \star$ significant at level of probability 0.05 and 0.01 , respectively. 
Both general (GCA) and specific (SCA) combining abilities mean squares were found to be highly significant for all studied traits, indicating the importance of both additive and non-additive genetic variances in determining the performance of these traits. These results are in line with those of AbdelMoneam (2005), Abdel-Moneam et al., (2009), Sultan et al. (2011), Attia et al. (2013), Sultan et al. (2013), Abdel-Moneam et al. (2014) and Wattoo et al. (2014).

GCA/SCA variances ratios were found to be lower than unity for six traits i.e. time to tassel emergency, time to silk emergency, number of rows/ear, number of kernels/row, grain yield/plant and shelling percentage, indicating the importance of non-additive genetic variance in the inheritance of these traits, therefore selection procedure in late or advanced generations will be very important to improve these traits. Similar results were reported by Sultan et al. (2011), Aminu et al. (2014) and Hemalatha et al. (2014). On the other hand, additive and additive $\times$ additive types of gene action were greater importance in the inheritance of plant height and 100-Kernel weight, therefore it concluded that the presence of large amounts of additive effects suggests the potentiality of selection procedure in early segregating generations for obtain further to improve these both traits. Similar results were reported by Uddin et al. (2006), Aliu et al. (2008), Muhammad et al. (2010), Haddadi et al. (2012), Attia et al. (2013) and Aminu et al. (2014).

\section{2- General combining ability effects $\left(g_{i}\right)$ :}

Estimates of general combining ability $\left(g_{i}\right)$ for inbred parents for all studied traits are shown in Table 4.

Estimates of GCA effects showed that, the parents P2 (P79) and P4 (Inb.1021) were found to be the best general combiners for earliness traits (time to $50 \%$ tassel emergence and time to $50 \%$ silk emergence), where they showed negative and significant or highly significant GCA effects for these traits. In the contrary, the other parents were found to be the worst general combiners for these traits.

With respect to plant height, inbred parents P5 (Inb.1004) and P6 (Oh.43) showed negative and highly significant GCA effects, indicating that these inbred parents were good general combiners for short stature. While, inbred parents P1 (R39) and P3 (B73) showed positive and highly significant GCA effects, indicating that these inbred parents are good general combiners for tallness.

Concerning to number of rows/ear, the inbred parent P5(Inb.1004) show positive highly significant GCA effects, indicating that this inbred parent is the best general combiner for increasing number of rows/ear. Whereas, inbred parent P3 (B73) show negative highly significant GCA effects, indicating that this parent is the worst general combiner for this trait.

With respect to number of kernels/row, the inbred parent P1 (R39) show positive significant GCA effects, indicating that this inbred parent is the best general combiner for increasing number of kernels/row. Whereas, inbred parents P3 (B73) and P6 (Oh.43) showed negative significant or highly significant GCA effects, indicating that these parents are the worst general combiners for this trait. 
Table 4: Estimates of general combining ability (GCA) effects $\left(g_{i}\right)$ for inbred parents for all studied traits.

\begin{tabular}{|c|c|c|c|c|c|}
\hline & & $\begin{array}{c}\text { Time to tassel } \\
\text { emergency }\end{array}$ & $\begin{array}{l}\text { Time to silk } \\
\text { emergency }\end{array}$ & Plant height & $\begin{array}{l}\text { Number of } \\
\text { rows/ear }\end{array}$ \\
\hline \multicolumn{2}{|l|}{ P1 (R39) } & 1.94 & 2.75 & 20.65 & 0.67 \\
\hline \multicolumn{2}{|l|}{ P2 (P97) } & -2.40 & -2.41 & 0.99 & -0.17 \\
\hline \multicolumn{2}{|l|}{ P3 (B73) } & 0.36 & -0.83 & 19.86 & -1.17 \\
\hline \multicolumn{2}{|l|}{ P4 (Inb.1021) } & $-1.64^{*}$ & $-1.67^{*}$ & -3.81 & -0.99 \\
\hline \multicolumn{2}{|l|}{ P5 (Inb.1004) } & 2.20 & 2.08 & -17.39 & $1.50^{\circ}$ \\
\hline \multicolumn{2}{|l|}{ P6 (Oh.43) } & -0.06 & 0.08 & $-20.31^{* *}$ & 0.17 \\
\hline LSD $\left(g_{i}\right)$ at & 0.05 & 1.45 & 1.34 & 5.02 & 1.07 \\
\hline \multirow{2}{*}{\multicolumn{2}{|c|}{ LSU $\left(g_{i}-g_{j}\right) a_{l}$}} & 2.24 & 2.08 & 7.77 & 1.66 \\
\hline & & $\begin{array}{c}\text { Number of } \\
\text { kernels/row }\end{array}$ & $\begin{array}{c}\text { 100-Kernel } \\
\text { weight }\end{array}$ & $\begin{array}{c}\text { Grain } \\
\text { yield/plant }\end{array}$ & $\begin{array}{c}\text { Shelling } \\
\text { percentage }\end{array}$ \\
\hline \multicolumn{2}{|l|}{ P1 (R39) } & 1.56 & -3.89 & 56.87 & 3.58 \\
\hline \multicolumn{2}{|l|}{ P2 (P97) } & 0.64 & 2.32 & -0.29 & 3.06 \\
\hline \multicolumn{2}{|l|}{ P3 (B73) } & -1.19 & 2.08 & -0.72 & -1.49 \\
\hline \multicolumn{2}{|l|}{ P4 (Inb.1021) } & -0.11 & 0.96 & $-36.35^{* *}$ & $-1.07^{*}$ \\
\hline \multicolumn{2}{|l|}{ P5 (Inb.1004) } & 0.89 & -0.68 & -13.78 & -3.76 \\
\hline \multicolumn{2}{|l|}{ P6 (Oh.43) } & $-1.78^{*}$ & $-0.78^{* *}$ & -5.73 & -0.32 \\
\hline LSD $\left(g_{i}\right)$ at & 0.05 & 1.24 & 0.49 & 12.46 & 0.67 \\
\hline LSD $\left(g_{i}-g_{j}\right)$ at & 0.05 & 1.91 & 0.75 & 19.29 & 1.04 \\
\hline
\end{tabular}

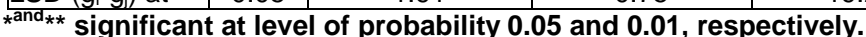

LSD $\left(g_{i}\right)$ Least significant differences for an GCA effect.

LSD $\left(g_{i}-g_{j}\right)$ Least significant differences for the difference between estimates of GCA effects.

In connection with 100-Kernel weight, estimates of GCA effects showed that the parents P2 (P97), P3 (B73) and P4 (Inb.1021) were found to be good general combiners for this trait, where they showed positive and highly significant GCA effects. While the other parents were found to be bad general combiners, for this trait.

Based on GCA estimates, it could be concluded that the best combiners for grain yield/plant was inbred parent of P1 (R39), where it showed positive and highly significant GCA effects for this trait. While other remaining were the worst general combiners for this trait, as shown in Table 4.

According to shelling percentage, it is clearly showed that inbred parents P1 (R39) and P2 (P97) recorded positive highly significant GCA effects, indicating that these inbred parents are the best general combiners for increasing shelling percentage. Whereas, the other remaining inbred parents showed negative GCA effects, indicating that these parents are the worst general combiners for this trait(Table,4). The obtained results completely agreed with the points of view which were reported by AbdelMoneam et al. (2009) and Hemalatha et al. (2014).

3- Specific combining ability effects $\left(\mathrm{S}_{\mathrm{ij}}\right)$ :

Estimates of specific combining ability (SCA) effects $\left(S_{i j}\right)$ for all $F_{1}$ single crosses for all studied traits are presented in Table 5.

Significant or highly significant negative SCA effects were found in earliness traits for some crosses. Based on SCA effects, it could be concluded that crosses i.e. P1 $\times$ P $3, \mathrm{P} 4 \times \mathrm{P} 6$ and $\mathrm{P} 5 \times \mathrm{P} 6$ for time to $50 \%$ tassel emergence, and crosses $\mathrm{P} 1 \times \mathrm{P} 2, \mathrm{P} 4 \times \mathrm{P} 6$ and $\mathrm{P} 5 \times \mathrm{P} 6$ for time to $50 \%$ silk emergence, showed significant or highly significant negative SCA effects, 
indicating that these crosses are the best combinations for improving earliness traits.

Table 5: Estimates of specific combining ability (SCA) effects $\left(s_{i j}\right)$ for $F_{1}$ single crosses for all studied traits.

\begin{tabular}{|c|c|c|c|c|c|}
\hline & & $\begin{array}{c}\text { Time to } \\
\text { tassel } \\
\text { emergency }\end{array}$ & $\begin{array}{l}\text { Time to silk } \\
\text { emergency }\end{array}$ & Plant height & $\begin{array}{c}\text { Number of } \\
\text { rows/ear }\end{array}$ \\
\hline \multicolumn{2}{|c|}{$\mathrm{P} 1 \times \mathrm{P} 2(\mathrm{R} 39 \times \mathrm{P} 97)$} & -0.51 & -3.33 & -3.05 & 0.83 \\
\hline \multicolumn{2}{|c|}{$\mathrm{P} 1 \times \mathrm{P3}(\mathrm{R} 39 \times \mathrm{B} 73)$} & -3.35 & -1.58 & -9.59 & -0.17 \\
\hline \multicolumn{2}{|c|}{ P1×P4 (R39×Inb.1021) } & -0.35 & -0.42 & 12.74 & -0.33 \\
\hline \multicolumn{2}{|c|}{ P1×P5 (R39×Inb.1004) } & -1.18 & 1.17 & 8.49 & 1.17 \\
\hline \multicolumn{2}{|c|}{$\mathrm{P} 1 \times \mathrm{P} 6$ (R39×Oh.43) } & 5.40 & 4.17 & -8.59 & -1.50 \\
\hline \multicolumn{2}{|c|}{ P2×P3 (P97×B73) } & 0.07 & 1.25 & -16.43 & 0.67 \\
\hline \multicolumn{2}{|c|}{ P2×P4 (P97×Inb.1021) } & 0.40 & 1.09 & 3.91 & -3.50 \\
\hline \multicolumn{2}{|c|}{ P2xP5 (P97×Inb.1004) } & -0.77 & -0.67 & 1.83 & 0.67 \\
\hline \multicolumn{2}{|c|}{ P2×P6 (P97×Oh.43) } & 0.82 & 1.66 & 13.74 & 1.33 \\
\hline \multicolumn{2}{|c|}{$\mathrm{P} 3 \times \mathrm{P} 4$ (B73×Inb.1021) } & 0.23 & -1.16 & -6.13 & 2.17 \\
\hline \multicolumn{2}{|c|}{ P3×P5 (B73×Inb.1004) } & 2.40 & 0.41 & 8.28 & -3.00 \\
\hline \multicolumn{2}{|c|}{$\mathrm{P} 3 \times \mathrm{P} 6$ (B73×Oh.43) } & 0.65 & 1.08 & 23.87 & 0.33 \\
\hline \multicolumn{2}{|c|}{ P4×P5 (Inb.1021×Inb.1004) } & $3.07^{*}$ & $3.25^{*}$ & -0.05 & 1.50 \\
\hline \multicolumn{2}{|c|}{ P4×P6 (Inb.1021×Oh.43) } & -3.35 & -2.75 & -10.47 & 0.17 \\
\hline \multicolumn{2}{|c|}{ P5×P6 (Inb.1004×Oh.43) } & -3.51 & -4.16 & -18.55 & -0.33 \\
\hline $\operatorname{LSD}\left(\mathrm{S}_{\mathrm{ij}}\right)$ & at 0.05 & 2.45 & 2.28 & 8.51 & 1.81 \\
\hline $\operatorname{LSD}\left(\mathrm{S}_{\mathrm{ij}}-\mathrm{S}_{\mathrm{ik}}\right)$ & at 0.05 & 3.88 & 3.60 & 13.46 & 2.87 \\
\hline $\operatorname{LSD}\left(\mathrm{S}_{\mathrm{ij}}-\mathrm{S}_{\mathrm{kl}}\right)$ & at 0.05 & 3.17 & 2.94 & 10.99 & 2.34 \\
\hline
\end{tabular}

. ${ }^{* a n d}{ }_{* \star}$ significant at level of probability 0.05 and 0.01 , respectively

- LSD $\left(S_{i j}\right)$ : Least significant differences for an SCA effect.

- $\operatorname{LSD}\left(\mathrm{S}_{\mathrm{ij}}-\mathrm{S}_{\mathrm{ik}}\right)$ :Least significant differences for the difference between two SCA effects for a common parent.

- $\operatorname{LSD}\left(\mathrm{S}_{\mathrm{ij}}-\mathrm{S}_{\mathrm{kl}}\right)$ :Least significant differences for the difference between two SCA effects for a non-common parent.

Regarding to plant height, five crosses i.e. $\mathrm{P} 1 \times \mathrm{P} 3, \mathrm{P} 1 \times \mathrm{P} 6, \mathrm{P} 2 \times \mathrm{P} 3$, $\mathrm{P} 4 \times \mathrm{P} 6$ and $\mathrm{P} 5 \times \mathrm{P} 6$ showed negative and significant or highly significant SCA effects, indicating that these crosses are the best combinations for improving shortness stature. In the contrary, the most of other crosses showed positive and highly significant SCA effects, indicating that these crosses are the best combinations for improving tallness stature.

Based on SCA effects, it could be concluded that, cross P $3 \times \mathrm{P} 4$ show significant and positive SCA effects for number of rows/ear, indicating that this cross is the best combination for increasing rows number/ear.

For number of kernels/row, results showed that the cross $\mathrm{P} 1 \times \mathrm{P} 5$ recorded positive significant SCA effects, indicating that this cross is the best combination for increasing kernels number/ear.

With respect to $100-$ Kernel weight, six crosses i.e. $\mathrm{P} 1 \times \mathrm{P} 3, \mathrm{P} 1 \times \mathrm{P} 6$, $\mathrm{P} 2 \times \mathrm{P} 3, \mathrm{P} 2 \times \mathrm{P} 5, \mathrm{P} 3 \times \mathrm{P} 5$ and $\mathrm{P} 4 \times \mathrm{P} 6$ showed positive significant or highly significant SCA effects, indicating that these crosses are the best combinations for improving the weight of $100-$ Kernel.

In connection with grain yield/plant, estimates of SCA effects showed that five crosses i.e. $\mathrm{P} 1 \times \mathrm{P} 2, \mathrm{P} 1 \times \mathrm{P} 5, \mathrm{P} 2 \times \mathrm{P} 5, \mathrm{P} 3 \times \mathrm{P} 6$ and $\mathrm{P} 4 \times \mathrm{P} 5$ recorded positive and significant or highly significant SCA effects, indicating that these crosses are the best combinations for improving grain yield/plant. 
Based on SCA effects, it could be concluded that, crosses i.e. $\mathrm{P} 1 \times \mathrm{P} 5, \mathrm{P} 3 \times \mathrm{P} 6$ and $\mathrm{P} 4 \times \mathrm{P} 5$ showed significant and positive SCA effects for shelling percentage, indicating that these crosses are the best combinations for improving this trait.

This means that, all of these crosses could be selected and used in breeding programs for improving all of these traits. These results are in confidence with those of Uddin et al. (2006), Abdel-Moneam et al. (2009) and Aminu et al. (2014).

Table 5: Continue .......

\begin{tabular}{|c|c|c|c|c|c|}
\hline & & $\begin{array}{c}\text { Number of } \\
\text { kernels/row }\end{array}$ & $\begin{array}{c}100 \text {-Kernel } \\
\text { weight }\end{array}$ & $\begin{array}{c}\text { Grain yield/ } \\
\text { plant }\end{array}$ & $\begin{array}{c}\text { Shelling } \\
\text { percentage }\end{array}$ \\
\hline $\mathrm{P} 1 \times \mathrm{P} 2$ (R39 & & -0.88 & -0.59 & $34.23^{* \prime}$ & -0.33 \\
\hline $\mathrm{P} 1 \times \mathrm{P} 3$ (R39 & & -3.71 & $1.43^{\circ}$ & -17.71 & -2.36 \\
\hline $\mathrm{P} 1 \times \mathrm{P} 4$ (R39 & & 1.20 & -1.09 & -15.04 & -0.48 \\
\hline $\mathrm{P} 1 \times \mathrm{P} 5$ (R39 & & 2.20 & -1.27 & 22.48 & 4.27 \\
\hline $\mathrm{P} 1 \times \mathrm{P} 6$ (R39 & & 1.20 & $1.53^{* *}$ & $-23.97^{*}$ & -1.10 \\
\hline P2×P3 (P97 & & -0.47 & 0.86 & -16.89 & 0.44 \\
\hline P2×P4 (P97 & & -1.22 & -0.03 & -29.35 & 0.16 \\
\hline P2×P5 (P97 & & 1.45 & 1.22 & $24.99^{*}$ & 0.47 \\
\hline P2×P6 (P97 & & 1.12 & -1.44 & -12.99 & -0.74 \\
\hline $\mathrm{P} 3 \times \mathrm{P} 4(\mathrm{~B} 73$ & & 1.95 & -2.31 & 1.70 & -2.31 \\
\hline P3×P5 (B73 & & 1.62 & 1.21 & -33.61 & -1.95 \\
\hline P3×P6 (B73 & & 0.62 & $-1.19^{*}$ & $66.51^{*}$ & $6.18^{*}$ \\
\hline P4×P5 (Inb. & 004) & -2.13 & 0.59 & 29.18 & 2.09 \\
\hline P4×P6 (Inb. & & 0.20 & 2.85 & 13.50 & 0.54 \\
\hline P5×P6 (Inb. & & -3.13 & $-1.75^{\circ}$ & -43.06 & -4.88 \\
\hline $\operatorname{LSD}\left(\mathrm{S}_{\mathrm{ij}}\right)$ & at 0.05 & 2.10 & 0.83 & 21.14 & 1.14 \\
\hline LSD $\left(\mathrm{S}_{\mathrm{ij}}-\mathrm{S}_{\mathrm{ik}}\right)$ & at 0.05 & 3.31 & 1.30 & 33.42 & 1.81 \\
\hline $\operatorname{LSD}\left(\mathrm{S}_{\mathrm{ij}}-\mathrm{S}_{\mathrm{kl}}\right)$ & at 0.05 & 2.71 & 1.07 & 27.29 & 1.47 \\
\hline
\end{tabular}

- *and** significant at level of probability 0.05 and 0.01 , respectively

- $\operatorname{LSD}\left(\mathrm{S}_{\mathrm{ij}}\right)$ : Least significant differences for an SCA effect.

- LSD $\left(\mathrm{S}_{\mathrm{ij}}-\mathrm{S}_{\mathrm{ik}}\right)$ : Least significant differences for the difference between two SCA effects for a common parent.

- LSD $\left(\mathrm{S}_{\mathrm{ij}}-\mathrm{S}_{\mathrm{kl}}\right)$ : Least significant differences for the difference between two SCA effects for a non-common parent.

- Estimates of heterosis.

Percentages of heterosis over mid and better parents for all studied traits are presented in Table 6.

With respect to time to $50 \%$ tassel emergence, results revealed that seven and three cross combinations manifested negative significant or highly significant heterosis over mid-parents and over better-parents, respectively. The highest negative heterosis percentages were exhibited by cross P4×P6 $(-22.86 \%$ and $-22.17 \%)$ over mid and better parents, respectively.

According to time to $50 \%$ silk emergence, results revealed that eleven and seven cross combinations manifested negative significant or highly significant heterosis over mid-parents and over better-parent, respectively. The highest negative heterosis percentages were exhibited by cross $\mathrm{P} 4 \times \mathrm{P} 6$ $(-20.44 \%$ and $-20.23 \%)$ over mid-parents and better-parent, respectively.

Short stature maize plants are preferred because plants with greater height are likely to lodge during wind storm. Therefore, the plant height heterosis in the negative direction is desirable. The results of heterosis 
showed that non of the cross combinations showed negative heterosis over mid and better parents.

Regarding to number of rows/ear, results indicated that nine of cross combinations manifested positive significant or highly significant heterosis over both mid and better-parent. The highest positive heterosis percentages were exhibited by cross P1×P5 (53.85\% and $42.86 \%)$ over mid and better parents, respectively.

In connection with number of kernels/row and 100-Kernel weight, the results of heterosis showed that all of the cross combinations showed significant or highly significant positive heterosis over mid and better parents, except cross P5×P6 over better parents for kernels number/row . The highest positive significant heterosis percentages were recorded by cross $\mathrm{P} 1 \times \mathrm{P} 6$ (143.43 and $123.94 \%)$ for kernels number/row and cross P2xP5(115.81 and $105.10 \%)$ for 100 - Kernel weight over mid and better parents, respectively.

Table 6: Percentages of heterosis over mid and better parents for all studied traits during 2013 summer growing season.

\begin{tabular}{|c|c|c|c|c|c|c|c|c|}
\hline & \multicolumn{2}{|c|}{$\begin{array}{l}\text { Time to tassel } \\
\text { emergence }\end{array}$} & \multicolumn{2}{|c|}{$\begin{array}{l}\text { Time to silk } \\
\text { emergence }\end{array}$} & \multicolumn{2}{|c|}{ Plant height } & \multicolumn{2}{|c|}{$\begin{array}{l}\text { Number of } \\
\text { rows/ear }\end{array}$} \\
\hline & M.P & B.P & M.P & B.P & M.P & B.P & M.P & B.P \\
\hline $\mathrm{P} 1 \times \mathrm{P} 2$ & -10.48 & -6.62 & -15.25 & $-11.77^{\prime \prime}$ & $69.10^{\circ}$ & 72.49 & 38.46 & 28.57 \\
\hline $\mathrm{P} 1 \times \mathrm{P} 3$ & -6.59 & 1.41 & -6.98 & 0.00 & $62.30^{\prime \prime}$ & 73.77 & 14.29 & 0.00 \\
\hline $\mathrm{P} 1 \times \mathrm{P} 4$ & $-13.18^{* *}$ & $-11.60^{*}$ & $-12.27^{*}$ & $-12.03^{* *}$ & $55.43^{* *}$ & $72.90^{* *}$ & $33.33^{*}$ & $33.33^{*}$ \\
\hline $\mathrm{P} 1 \times \mathrm{P} 5$ & -1.61 & 3.34 & -0.28 & 3.51 & $66.08^{-1}$ & 70.97 & $53.85^{\prime \prime}$ & 42.86 \\
\hline $\mathrm{P} 1 \times \mathrm{P} 6$ & 0.89 & 1.81 & -2.17 & -2.17 & 65.92 & 87.81 & 33.33 & 33.33 \\
\hline $\mathrm{P} 2 \times \mathrm{P} 3$ & -5.15 & -1.44 & -7.27 & -4.37 & $49.08^{m}$ & 63.03 & 6.67 & 0.00 \\
\hline $\mathrm{P} 2 \times \mathrm{P} 4$ & -17.14 & -11.92 & -15.02 & $-11.77^{\prime \prime}$ & 41.42 & 60.79 & -7.69 & -14.29 \\
\hline $\mathrm{P} 2 \times \mathrm{P} 5$ & -6.00 & -5.38 & $-8.51^{\prime \prime}$ & -8.24 & 51.68 & 53.06 & 33.29 & 33.29 \\
\hline $\mathrm{P} 2 \times \mathrm{P} 6$ & -12.58 & -7.95 & -11.31 & -7.66 & $71.53^{\prime \prime}$ & 89.98 & 38.46 & $28.57^{\circ}$ \\
\hline $\mathrm{P} 3 \times \mathrm{P} 4$ & $-8.40^{\circ}$ & 1.41 & -13.71 & -7.50 & $35.47^{\prime \prime}$ & 40.43 & 19.00 & 4.13 \\
\hline $\mathrm{P} 3 \times \mathrm{P} 5$ & 10.03 & 13.56 & -0.92 & 2.49 & $54.21^{\prime \prime}$ & 70.29 & -6.67 & -12.50 \\
\hline $\mathrm{P} 3 \times \mathrm{P} 6$ & -3.60 & 5.70 & $-6.98^{*}$ & 0.00 & $74.84^{* *}$ & $113.53^{* *}$ & 14.29 & 0.00 \\
\hline $\mathrm{P} 4 \times \mathrm{P} 5$ & -2.20 & 4.69 & -3.97 & -0.60 & 29.32 & 48.52 & 43.54 & 33.29 \\
\hline $\mathrm{P} 4 \times \mathrm{P} 6$ & -22.86 & -22.17 & -20.44 & -20.23 & 30.64 & 66.44 & 33.33 & 33.33 \\
\hline $\mathrm{P} 5 \times \mathrm{P} 6$ & -10.77 & -5.38 & -13.80 & -10.53 & $12.93^{m}$ & 24.71 & 38.46 & 28.57 \\
\hline LSD at 0.05 & 3.66 & 4.23 & 3.51 & 4.06 & 11.95 & 13.80 & 3.08 & 3.56 \\
\hline $\mathrm{P} 1 \times \mathrm{P} 2$ & 85.20 & 56.92 & 74.09 & 62.32 & 479.49 & 383.84 & 10.33 & 7.89 \\
\hline $\mathrm{P} 1 \times \mathrm{P} 3$ & $59.65^{* *}$ & $33.77^{*}$ & $55.26^{* *}$ & 39.78 & $190.75^{*}$ & $92.85^{* *}$ & $3.46^{* *}$ & 2.24 \\
\hline $\mathrm{P} 1 \times \mathrm{P} 4$ & $124.98^{\circ}$ & 116.67 & 35.06 & 23.13 & 321.85 & 260.85 & 17.21 & 7.57 \\
\hline $\mathrm{P} 1 \times \mathrm{P} 5$ & 75.70 & 36.67 & 39.72 & 36.92 & 269.57 & 156.82 & 8.23 & 6.41 \\
\hline $\mathrm{P} 1 \times \mathrm{P} 6$ & 143.43 & 123.94 & 45.98 & 37.52 & 562.16 & 462.21 & 10.00 & 7.73 \\
\hline $\mathrm{P} 2 \times \mathrm{P} 3$ & $45.18^{*}$ & $43.21^{* \prime}$ & 101.96 & $70.88^{\prime \prime}$ & $97.05^{* *}$ & $46.56^{\prime \prime}$ & $3.88^{*}$ & $2.77^{*}$ \\
\hline $\mathrm{P} 2 \times \mathrm{P} 4$ & 69.81 & 48.58 & 92.03 & 64.38 & 126.11 & 119.60 & 14.48 & 2.94 \\
\hline $\mathrm{P} 2 \times \mathrm{P} 5$ & 45.67 & 31.10 & 115.81 & 105.10 & 156.93 & 103.23 & 0.66 & 0.11 \\
\hline $\mathrm{P} 2 \times \mathrm{P} 6$ & 91.21 & 51.38 & 78.22 & 57.23 & 307.14 & 198.77 & 7.24 & $2.75^{n}$ \\
\hline $\mathrm{P} 3 \times \mathrm{P} 4$ & 73.42 & 49.98 & 47.96 & $45.91^{\prime \prime}$ & 81.18 & 32.21 & 6.45 & -3.35 \\
\hline $\mathrm{P} 3 \times \mathrm{P} 5$ & 37.77 & 25.53 & 76.76 & 56.30 & 32.50 & 21.75 & -6.69 & -7.17 \\
\hline $\mathrm{P3} 3 \times \mathrm{P} 6$ & $75.85^{*}$ & $37.82^{*}$ & $49.55^{* *}$ & $42.49^{\prime \prime}$ & $243.03^{*}$ & $110.61^{*}$ & $11.42^{* \prime \prime}$ & 7.86 \\
\hline $\mathrm{P} 4 \times \mathrm{P} 5$ & 45.83 & 16.67 & 68.52 & 50.85 & 122.13 & 71.97 & 8.66 & -1.80 \\
\hline $\mathrm{P} 4 \times \mathrm{P} 6$ & 116.63 & 92.56 & 68.93 & 63.13 & 300.93 & 199.95 & $15.90^{\circ}$ & 8.45 \\
\hline P5 $\times$ P6 & $46.95^{* *}$ & 7.77 & $48.32^{* *}$ & $37.10^{*}$ & $106.20^{*}$ & 31.16 & $-5.81^{* *}$ & $-9.27^{*}$ \\
\hline LSD at 0.05 & 3.27 & 3.77 & 1.25 & 1.44 & 29.95 & 34.59 & 1.86 & 2.14 \\
\hline
\end{tabular}

"and" significant at level of probability 0.05 and 0.01 , respectively 
Regarding to grain yield/plant, results revealed that all cross combinations manifested positive significant or highly significant heterosis over mid and better parents, except cross $\mathrm{P} 3 \times \mathrm{P} 5$ over better parents .The highest positive heterosis effect were exhibited by cross P1×P6 (562.16 and 462.21\%) over mid and better parents, respectively.

With respect to shelling percentage, results revealed that most of cross combinations manifested positive significant or highly significant heterosis over mid-parents (12 crosses) and over better-parents ( 9 crosses). The highest positive heterosis percentages were exhibited by cross P1×P4 (17.21\%) over mid parents and P4×P6 (8.45\%) over better parent. These results are in confidence with those of Abdel-Moneam et al. (2009), Patel et al. (2009), Amiruzzaman et al. (2010), Amanullah et al. (2011), Solomon et al. (2012), Attia et al. (2013) and AbdelMoneam et al. (2014).

\section{REFERENCES}

Abdel-Moneam, M.A. (2005). Comparison of the response of some different maize genotypes to cultivation under moisture stress conditions. Ph.D. Thesis. Agron. Dept., Fac. of Agric., Mansoura Univ., Egypt.

Abdel-Moneam, M.A. ; M.S. Sultan ; S.M.G. Salama and A.M. El Oraby (2014). Evaluation of combining ability and heterosis for yield and its components traits of five maize inbreds under normal and stress nitrogen fertilization. Asian J. of Crop Sci., 6(2): 142-149.

Abdel-Moneam, M.A.; A.N.E. Attia; M.I. EL-Emery and Eman A. Fayed (2009). Combining ability and heterosis for some agronomic traits in crosses of maize. Pakistan J. of Biological Sci., 12(5): 433-438.

Aliu, S. ; Sh. Fetahu and A. Salillari (2008). Estimation of heterosis and combining ability in maize (Zea mays L. ) for ear weight (EW) using the diallel crossing method. Latvian J. of Agron., 11: 1-12(C.F. Computer Search).

Amanullah, S.; M. Mansoor and M. Anwar khan (2011). Heterosis studies in diallel crosses of maize. Sarhad J. Agric., 27(2): (C.F. Computer Search).

Aminu, D. ; S.G. Mohammed and B.G. Kabir (2014). Estimates of combining ability and heterosis for yield and yield traits in maize population (Zea mays L.), under drought conditions in the Northern Guinea and Sudan Savanna zones of Borno state, Nigeria. Intern. J. of Agric. Innovations and Res., 2 (5): 824-830: (C.F. Computer Search).

Amiruzzaman, M.; M. A. Islam; L. Hassan and M.M. Rohman (2010). Combining ability and heterosis for yield and component characters in maize. Academic J. of Plant Sci., 3(2): 79-84.

Attia, A.N.E ; M.A. Badawi ; A.M. Salama; M.A. Abdel-Moneam and A.A.A Leilah (2013). Combining ability and heterosis for maize grain yield and some agronomic characters. J. Plant Production, Mansoura Univ., 4(4): 551-560.

Darwin,C. (1876). The effects of cross and self-fertilisation in vegetable kingdom .London: John Murray, Albemarle Street. (C.F. Computer Search).

El-Diasty, M.Z. (2013). A Comparative study between two mating designs to estimate different genetic parameters in corn (Zea mays L.). Ph. D. Thesis, Genetics Dept., Fac. of Agric., Mansoura Univ., Egypt. 
El-Ghonemy, M.A. and M.H.A. Ibrahim (2010). Diallel analysis of yellow maize for combining ability and heterosis. J. Plant Production, Mansoura Univ., 1(6): 779-792.

Gomez, K.N. and A.A. Gomez (1984). Statistical procedures for agricultural research. John Wiley and Sons, New York, $2^{\text {nd }}$ ed., 68 p.

Griffing, B. (1956). Concept of general and specific combining ability in relation to diallel crossing systems. Aust. J. Biol. Sci., 9: 463-493.

Guerrero, C.G. ; M.A.G. Robles ; J.G.L. Ortega ; I.O. Castillo ; C.V. Vázquez ; M.G. Carrillo; A.M. Resendez and A.G. Torres (2014). Combining ability and heterosis in corn breeding lines to forage and grain. American J. of Plant Sci., 5: 845-856.

Guznay, J.B.A. and H.A. Sadalla (2011). Estimation of genetic parameters, genetic advance and genetic resultant for maize genotypes (Zea mays L.). National Maize Research program, Bako Research Center, P.O. Box 3 West Shoa, Ethiopia.139-142. (C.F. Computer Search).

Haddadi, M.H. ; M. Eesmaeilof ; R. Choukan and V. Rameeh (2012). Combining ability analysis of days to silking, plant height, yield components and kernel yield in maize breeding lines. African $\mathrm{J}$. of Agric. Res., 7(33): 4685-4691.

Hemalatha, V. ; R. Sai-Kumar ; V. Swarnalatha and J. Suresh (2014). Combining ability and gene action for morphological parameters in quality protein maize (Zea mays L.). Intern. J. of Plant, Animal and Environ. Sci., 4 (2): 230-235.

Mather, K. and J. L. Jinks (1982). Biometrical Genetics. $3^{\text {rd }}$ ed. Chapman and Hall, London.

Muhammad, I.; S.U. Ajmal ; M. Muhammad and G. Muhammad (2010). Gene action studies of different quantitative traits in maize. Pakistan J. of Botany, 42:(2) 1021-1030.

Patel, C. G. ; D. B. Patel ; N. B. Prajapati ; M. D. Patel and K.R. Patel (2009). Heterosis breeding in maize (Zea mays L.). International J. of Plant Sci., 4(2): 513-516.

Shalof, M.S.I (2012). Breeding studies on maize (Zea mays L.). M. Sc. Thesis, Fac. Agric., Mansoura Univ., Egypt.

Solomon, K.F. ; A. Zeppa and S.D. Mulugeta (2012). Combining ability, genetic diversity and heterosis in relation to $F_{1}$ performance of tropically adapted shrunken (sh2) sweet corn lines. Plant Breeding, 131 (3): 430-436.

Sultan, M. S. ; A. A. El-Hosary; A. A. Lelah ; M. A. Abdel Moneam and M.A. Hamouda (2011). Combining ability for some important traits in red maize using Griffing's method 2 and 4 . J. of Plant production, Mansoura Univ., 2(6): 811-822.

Sultan, M.S.; M.A. Abdel-Moneam ; S.M.G. Salama and A.M. El-Oraby (2013). Combining ability and heterosis for some flowering and vegetative traits of five maize inbreds under two nitrogen levels fertilization. J. of Plant production, Mansoura Univ., 4(2): 749-766.

Uddin, M.S. ; F. Khatun ; S. Ahmed ; M.R. Ali and S.A. Bagum (2006). Heterosis and combining ability in corn (Zea mays L.). Bangladesh $\mathrm{J}$. Bot., 35(2): 109-116. 
Waller, R.A. and D.B. Duncan (1969). A bays rule for the symmetric multiple comparison problem. J. Amer. Assoc., 64: 1484-1503.

Wattoo, F.M. ; M. Saleem and M. Sajjad (2014). Identification of potential $F_{1}$ hybrids in maize responsive to water deficient condition. American J. of Plant Sci., 5: 1945-1955.

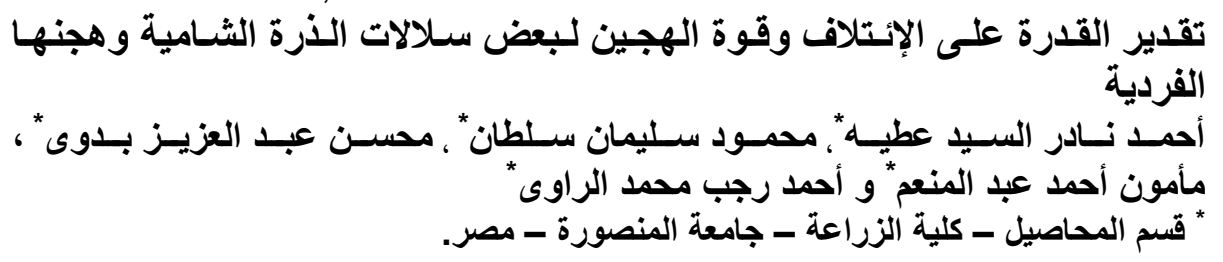

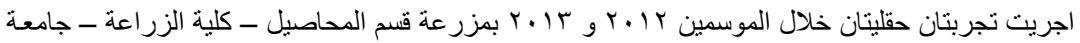

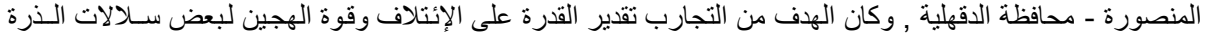

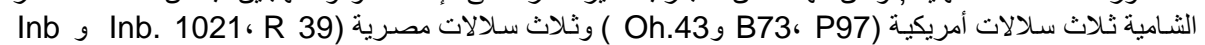

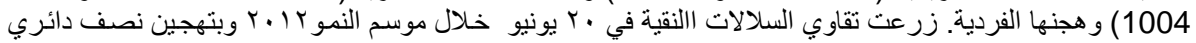

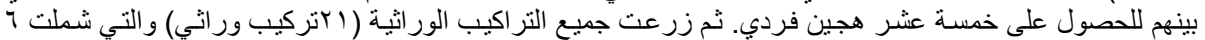

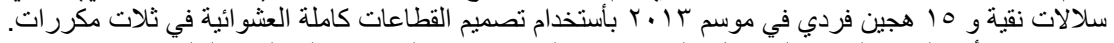

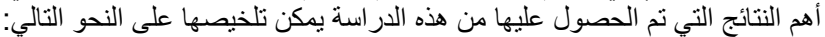

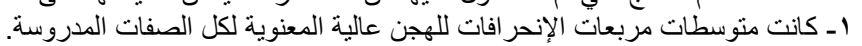

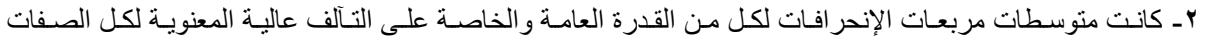

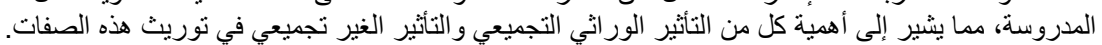

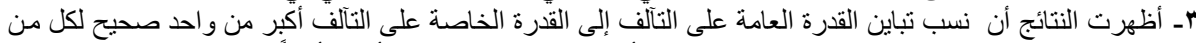

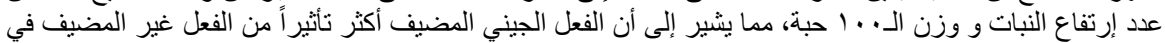

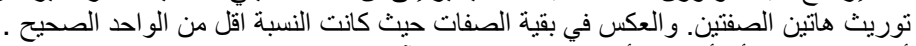

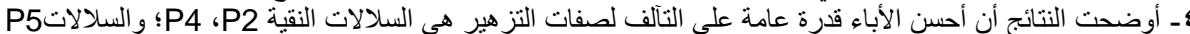

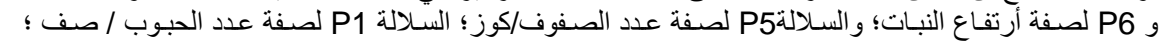

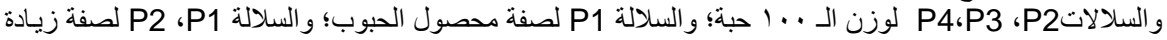
نسبة التفريط.

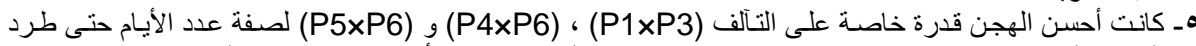

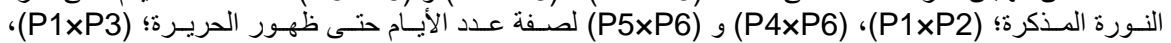

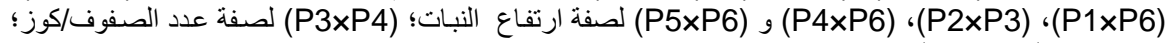

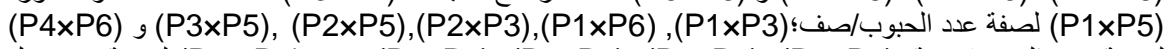

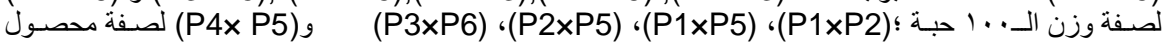

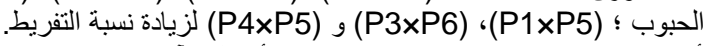

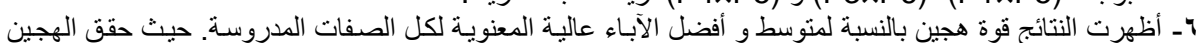
(P4×P6)

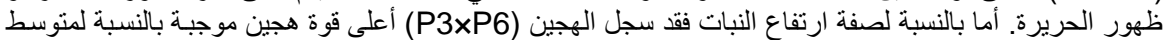

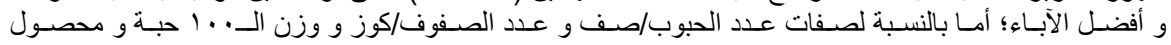

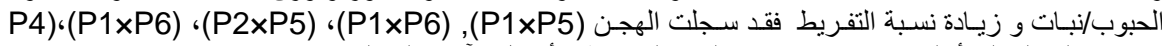

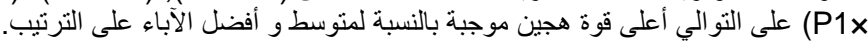

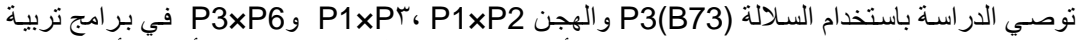

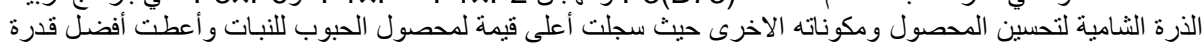
على التألف. 